\title{
Variation of rice varieties of Russian breeding by grain quality traits in growing conditions of agrolandscape zones of Krasnodar region
}

\author{
Natalia Tumanian*, Svetlana Chizhikova, Elina Papulova, Tatyana Kumeiko and Sergey \\ Garkusha
}

Federal State Budgetary Scientific Institution «Federal Scientific Rice Centre» Belozerny, 3, Krasnodar, 350921, Russia

\begin{abstract}
The technological grain quality traits of varieties of the Federal Scientific Rice Centre (Rapan., Rapan 2, Favorit, Nautilus, Yakhont, Olimp, Patriot) grown in the old-delta and valley agrolandscape zones of Krasnodar region (Russia) in 2017-2019 were studied. The studied rice varieties are included in the State register of breeding achievements approved for use in the North Caucasus region in 2014-2019, Rapan 2 is under state variety testing. Most of the varieties under study showed the highest values of grain quality traits in the valley agrolandscape in 2019 , in the old-delta - in 2018, which indicates the reaction of the varieties to agroclimatic conditions of vegetation. The best varieties for grain quality on the basis of low variability in the aggregate of all quality traits were recognized as Favorit for the valley agrolandscape zone of Krasnodar region (predecessor - fallow field), and Rapan 2 for the old delta agrolandscape zone (predecessor - winter wheat). According to the absolute values of the traits characterizing the yield and milled rice quality, the best variety in the valley agrolandscape was Yakhont, and in the olddelta, Nautilus. The placement of rice varieties in agrolandscape zones of Krasnodar region is recommended taking into account their reaction to agroclimatic conditions of cultivation.
\end{abstract}

\section{Introduction}

Rice, being one of the main food crops, has a wide distribution area in many countries of the world. More than half of the world's population uses rice as a staple food. In Russian Federation, this crop is grown mainly in Krasnodar region, where more than $80 \%$ of rice is produced and the share of milled rice consumption is about $29 \%$. The main requirement for the profitability of rice production is development of high-yielding, resistant to disease and lodging rice varieties. In recent years, with the changing market conditions, priority has been given to consumer support for the quality and competitiveness of rice varieties developed by domestic breeders.

Complex of quality traits of rice yield is determined by the genotype of the variety and its response to agroclimatic conditions of cultivation. The urgency of the problem is to

\footnotetext{
${ }^{*}$ Corresponding author: tngerag@yandex.ru
} 
identify the patterns of reaction of rice varieties to changes in agroclimatic conditions and traits of their environmental stability. Grain in some varieties shows an increase in the quality traits, in others it decreases, the rest show genotype stability regardless of the climatic conditions of the growing season, expanding the range of potential in breeding modern rice varieties.

In the Kuban, rice is grown in five agrolandscape zones: transitional-delta, old-delta, valley, extra-delta and young-delta. To obtain rice grain yields with high grain quality, research is being conducted on breeding Russian varieties for different rice growing zones. Under various conditions of interaction of the genotype with the environment, agroclimatic conditions, as a rule, exceed the effect of the variety when cultivated. At the end of the 90s, varieties for different regions of Krasnodar region were already bred at Federal Scientific Rice Centre (ARRRI). In rice-producing countries of the world, studies are carried out related to the study of the effective cultivation of new productive rice varieties with high quality.

There are known works on the assessment of phenotypic and genotypic variation, correlation of rice grain quality traits $[1,2,3,4]$. One of the important goals in plant breeding programs in Iran is the development and production of high quality genotypes, including study of the correlation of rice grain quality traits in breeding samples [5]. When growing varieties of Egyptian breeding, it was shown that the methods of sowing seeds and seedlings influenced grain size, yield and milled rice quality[6]. Studies are being conducted on the correlation of quality and yield traits of Turkish varieties under growing conditions in Bulgaria [7]. In India, the quality of yield of rice varieties of various origin grown in saline lands in Tamil Nadu was studied. The values of phenotypic coefficients of variation were slightly higher than genotypic ones, which testified to a slight effect of agroclimatic conditions on quality traits[8]. At S.V Agricultural College (India, Tirupati), a study was conducted of the influence of fourteen growing factors on 32 rice genotypes, yield and quality, and their relationship was shown. It was concluded that breeding based on these traits could contribute to the simultaneous improvement of yield and quality traits [9]. In studies of indicators of variability, coefficients of variation of traits are often used [10]. Based on the absolute values of quality traits and their variability, regression models of quality traits were constructed and varieties were grouped by the traits [11]. The variability of varieties grown under the conditions of traditional technology and when using organic fertilizers (Texas) according to biochemical quality traits was shown [12].

In connection with the foregoing, purpose of the work was to study the technological grain quality traits of varieties bred in Federal Scientific Rice Centre grown in the old-delta and valley agrolandscape zones of Krasnodar region (Russia) in 2017 - 2019.

\section{Materials and Methods}

The research material was varieties of Federal Scientific Rice centre: Rapan 2, Favorit, Nautilus, Yakhont, Olimp, Patriot, grown in the farms of the old-delta (Krasnoarmeysky district) and in the valley (Abinsky district) agrolandscape zones in 2017-2018. Variety Rapan was used as a standard. The predecessor in the valley agrolandscape zone was fallow field, in the old-Delta zone - winter wheat. The studied rice varieties are included in the State register of breeding achievements approved for use in the North Caucasus region: Favorit - in 2014, Olimp - in 2015, Patriot - in 2017, Nautilus and Yakhont - in 2019, Rapan 2 is in state variety testing. Rice grain samples were taken in the phase of full ripeness. Agroclimatic conditions of the valley agrolandscape (Abinsky district): the soils of the plot are represented by a complex of meadow-chernozem medium heavy loamy soils; the thickness of the humus horizon is $75 \mathrm{~cm}$, the humus content is $5.1 \%$. The reaction of the soil solution in the arable horizon is neutral - $\mathrm{pH}$ 6.8-7.2. The proportion of absorbed 
calcium is $65-70 \%$, absorbed magnesium - up to $25 \%$. The content of gross nitrogen is $0.22-0.26 \%$, total phosphorus is $0.18-0.20 \%$. The content of easily hydrolyzable nitrogen is 8.7-10.3 mg / $100 \mathrm{~g}$; mobile phosphorus 9.3-12.2 mg / $100 \mathrm{~g}$; mobile potassium 43.2-45.8 $\mathrm{mg} / 100 \mathrm{~g}$. Agroclimatic conditions of the old-delta agrolandscape (Krasnoarmeysky district): rice, meadow-chernozem soils, formed mainly in the modern Kuban river delta on alluvial rocks; the thickness of the humus horizon is $100-130 \mathrm{~cm}$, the humus content is 2.8 - $3.7 \%$, the total nitrogen and phosphorus contents are $0.20-0.25$ and $0.18-0.20 \%$, respectively. The content of easily hydrolyzable nitrogen $5-7 \mathrm{mg} / 100 \mathrm{~g}$ of soil; mobile phosphorus $2-3 \mathrm{mg} / 100 \mathrm{~g}$ of soil. The reaction of the soil solution in the arable horizon is neutral - $\mathrm{pH}$ 6.8-7.2.

Technological characteristics of quality were determined by GOST methods: filminess according to GOST 10843-76 (on a Satake peeling plant), vitreousity - according to GOST 10987-76, grain size by weight of 1000 absolutely dry grains (weight of 1000 a.d. grains) according to GOST 10842-89, fracture - on a DSZ-3 diaphanoscope, yield and grain quality - on a LUR-1 M installation. Mathematical and statistical data processing was performed by calculations in Microsoft Exel.

\section{Results and Discussion}

Rice grain quality traits are subject to variability due to the agro-climatic conditions of rice cultivation. The most important characteristic of a variety is its ability to form a high quality yield in changing environmental conditions. Risk factors in formation of grain yield quality depending on the length of the growing season are the sum of daily average temperatures and average decade air temperature. The sum of the average daily temperatures for rice is in the range from 2000 to $3000^{\circ} \mathrm{C}$, when passing to seedling stage $-520^{\circ} \mathrm{C}$, to filling stage $-700^{\circ} \mathrm{C}$. Changes in the relevant temperature indicators during the growing season can cause a sharp decrease in grain quality - increase in fracturing and, as a result, a decrease in the yield of final products of high quality. The sum of the effective temperatures and the average decade air temperature from April to September 2017-2019 are presented in Figures 1 and 2.

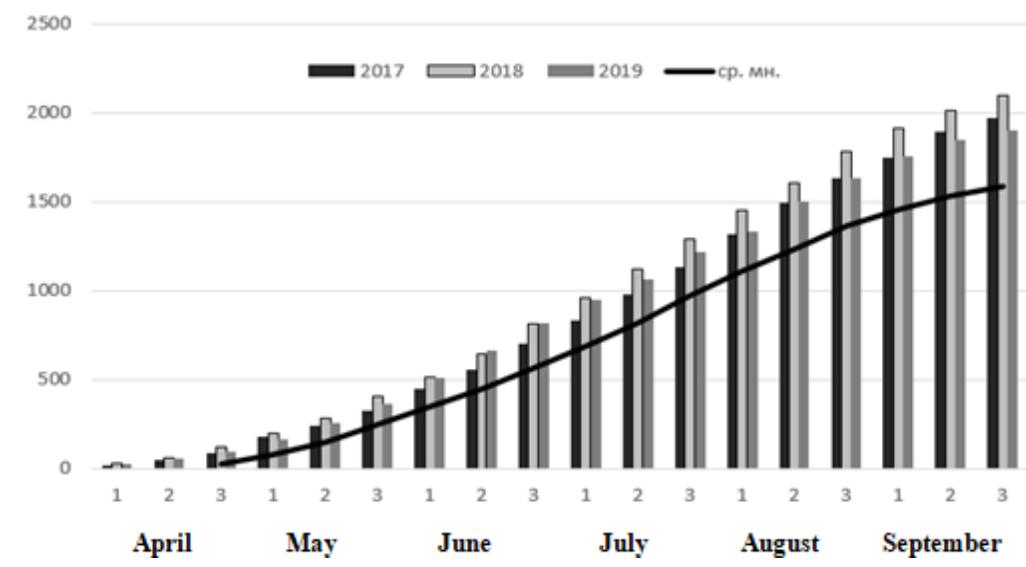

Fig. 1. The sum of the effective temperatures (above $10^{\circ} \mathrm{C}$ ) in April-September $2017-2019,{ }^{\circ} \mathrm{C}$

The crucial stage of the production process in rice is the period of grain filling, when its metabolism is aimed at providing the generative organs with assimilates and mineral 
elements. On the intensity of their movement from the vegetative organs to the panicle depends the rate of grain filling, weight of 1000 grains and the yield of the variety [6]. In 2017, 2018 and 2019, studies of the sum of effective temperatures at the end of August, towards the end of the grain filling period, reached the values of 1632,1781 and $1635^{\circ} \mathrm{C}$, respectively (Figure 1). These indicators were significantly higher than the average sum of effective temperatures according to long-term data. Moreover, the increase in the sum of effective temperatures was significant in May and continued throughout the entire growing season. The largest increase in the sum of effective temperatures was observed in 2018.

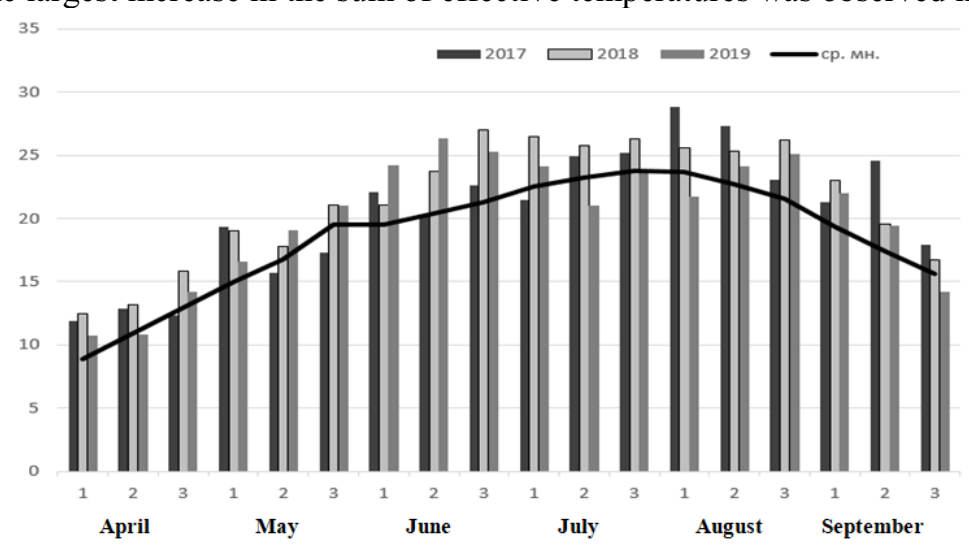

Fig 2. The average decade air temperature in April-September $2017-2019,{ }^{\circ} \mathrm{C}$

The average decade temperature in the third decade of August, the conditions of which determine the grain filling, was maximum in 2018 and amounted to $26.2^{\circ} \mathrm{C}$ and minimum in $2017-23.1^{\circ} \mathrm{C}$ (Figure 2). In the initial ripening period, which occurs in the first decade of August, the maximum average decade temperature was observed in 2017 and amounted to $28.8^{\circ} \mathrm{C}$, the minimum - in $2019\left(21.7^{\circ} \mathrm{C}\right)$. In the second decade of August, the maximum decade-long temperature in 2017 was $27.3^{\circ} \mathrm{C}$, and the minimum in $2019-24.1$ ${ }^{\circ} \mathrm{C}$.

Technological characteristics of rice grain quality of rice varieties grown in the valley and old-delta agrolandscapes in 2017 - 2019 are presented in Tables 1 and 2. Weight of 1000 absolutely dry grains was the largest in 2017 among the varieties Favorit $(28.4 \mathrm{~g})$, Yakhont (28.3 g), Olimp (23.5 g) and Patriot (27.4 g) grown in the valley agrolandscape (Table 2). In variety Nautilus, the maximum value of the trait was noted in 2018: weight of 1000 absolutely dry grains were higher by $1.4 \mathrm{~g}$ than in 2017 and $2 \mathrm{~g}$ than in 2018 . For the majority of the studied varieties, the smallest values of the trait were noted in 2018: the difference with the largest mass of 1000 absolutely dry grains in variety Rapan 2 was $2.2 \mathrm{~g}$, in Favorit $-1.7 \mathrm{~g}$, in Yakhont - $1.9 \mathrm{~g}$, in Olimp - $2.9 \mathrm{~g}$. The trait values did not significantly differ in 2018 and 2019. The variety Nautilus had the smallest mass of 1000 absolutely dry grains in $2019(24.5 \mathrm{~g})$. 
Table 1. Technological grain quality traits of rice varieties grown in a valley agrolandscape

\begin{tabular}{|c|c|c|c|c|c|c|}
\hline Variety & Year & 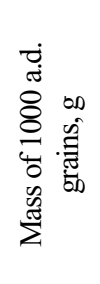 & 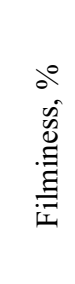 & 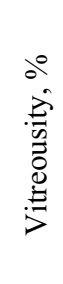 & 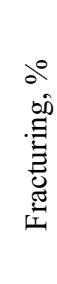 & 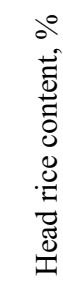 \\
\hline \multirow{3}{*}{ Rapan, st } & 2017 & 24,7 & 19,8 & 91 & 28 & 78,8 \\
\hline & 2018 & 22,5 & 18,5 & 93 & 40 & 62,8 \\
\hline & 2019 & 24,6 & 20,0 & 94 & 14 & 94,1 \\
\hline \multirow{3}{*}{ Rapan 2} & 2017 & - & - & - & - & - \\
\hline & 2018 & 22,6 & 19,6 & 89 & 34 & 65,4 \\
\hline & 2019 & 24,8 & 20,7 & 95 & 12 & 94,1 \\
\hline \multirow{3}{*}{ Favorit } & 2017 & 28,4 & 18,0 & 81 & 13 & 84,7 \\
\hline & 2018 & 26,7 & 18,1 & 87 & 20 & 70,1 \\
\hline & 2019 & 26,9 & 20,1 & 86 & 18 & 83,6 \\
\hline \multirow{3}{*}{ Nautilus } & 2017 & 25,1 & 19,0 & 86 & 24 & 78,8 \\
\hline & 2018 & 26,5 & 19,2 & 91 & 28 & 75,7 \\
\hline & 2019 & 24,5 & 16,5 & 93 & 12 & 93,2 \\
\hline \multirow{3}{*}{ Yakhont } & 2017 & 28,3 & 17,7 & 94 & 16 & 91,1 \\
\hline & 2018 & 26,4 & 17,9 & 90 & 20 & 71,6 \\
\hline & 2019 & 27,5 & 16,8 & 95 & 10 & 92,1 \\
\hline \multirow{3}{*}{ Olimp } & 2017 & 23,5 & 17,7 & 88 & 30 & 77,8 \\
\hline & 2018 & 20,6 & 18,2 & 86 & 14 & 87,6 \\
\hline & 2019 & 22,2 & 20,7 & 90 & 24 & 91,3 \\
\hline \multirow{3}{*}{ Patriot } & 2017 & 27,4 & 16,5 & 88 & 26 & 82,4 \\
\hline & 2018 & 25,4 & 18,1 & 85 & 20 & 69,7 \\
\hline & 2019 & 25,4 & 20,0 & 88 & 21 & 89,8 \\
\hline $\mathrm{LSD}_{05}$ & & 0,1 & 0,2 & 0,9 & 1 & 1,0 \\
\hline
\end{tabular}

The greatest filminess in most varieties in the experiment was noted in 2019, the smallest - in 2017. Characteristic values in 2019 were higher than in 2017 by $2.1 \%$ in variety Favorit, by $3 \%$ in Olimp, by $3,5 \%$ in the variety Patriot. The maximum filminess in the varieties Nautilus and Yakhont was in 2018, where the values of the trait increased by $2.7 \%$ in the variety Nautilus and by $1.1 \%$ in the variety Yakhont compared to 2019 . The maximum vitreousity among the studied varieties was noted in 2019 in the varieties Rapan 2 and Yakhont (95\%), Nautilus (93\%), Olimp (90\%), where the values of the trait were higher by $6 \%$ for Rapan 2, 5\% for Yakhont, $7 \%$ for Nautilus and $4 \%$ for Olimp, compared with the years where the vitreousity was the smallest. In variety Patriot, the trait values did not significantly differ in 2017 and 2019. The smallest vitreousity was observed in varieties Rapan 2 (89\%), Yakhont (90\%), Olimp (86\%) in 2018; in the varieties Favorit and Nautilus in 2017.

In the majority of the studied varieties, the greatest fracturing was noted in 2018 , the smallest in 2019.The trait values were higher in 2018 by $22 \%$ for Rapan 2, $16 \%$ for Nautilus, $10 \%$ for Yakhont than in 2019. The minimum values of the trait for varieties Olimp (14\%) and Patriot (20\%) were noted in 2018; in Favorit (13\%) in 2017. Fracturing difference between 2018 and 2017 accounted for 16 and 6\% in varieties Olimp and Patriot; between 2017 and 2018 - 7\% in the variety Favorit. For all studied varieties, the values of the trait "head rice content" were maximum in 2019 and exceeded the values of the trait in 2018 by $28.7 \%$ in variety Rapan 2 , by $17.5 \%$ in variety Nautilus, by $20.5 \%$ in variety 
Yakhont, $20.1 \%$ in the variety Patriot; in 2017 , by $13.5 \%$ in the variety Olimp, where the head rice content was minimal. The exception was Favorit, which had the highest head rice content $(84.7 \%)$ in 2017 , which is by $14.6 \%$ higher compared to 2018 , where the value of the trait was minimal.

Thus, in the majority of the studied varieties, the highest values of grain quality traits in the valley agrolandscape were noted in 2019 , which indicates the reaction of varieties to agroclimatic conditions of vegetation.

Technological grain quality traits of rice varieties grown in the old-delta agrolandscape are presented in Table 2 .

Table 2. Technological grain quality traits of rice varieties grown in the old-delta agrolandscape

\begin{tabular}{|c|c|c|c|c|c|c|}
\hline Variety & Year & 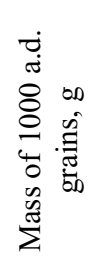 & 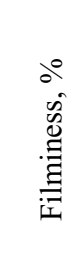 & 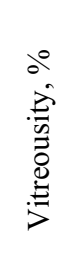 & 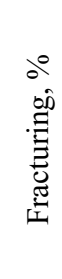 & 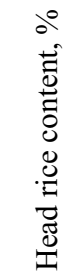 \\
\hline \multirow{3}{*}{ Rapan, st } & 2017 & 25,4 & 19,8 & 86 & 27 & 83,1 \\
\hline & 2018 & 24,9 & 21,8 & 92 & 38 & 62,6 \\
\hline & 2019 & 24,6 & 19,8 & 85 & 33 & 66,8 \\
\hline \multirow{3}{*}{ Rapan 2} & 2017 & - & - & - & - & - \\
\hline & 2018 & 25,6 & 18,4 & 92 & 11 & 91,0 \\
\hline & 2019 & 25,0 & 17,5 & 94 & 15 & 90,3 \\
\hline \multirow{3}{*}{ Favorit } & 2017 & 28,7 & 18,5 & 88 & 11 & 88,3 \\
\hline & 2018 & 29,9 & 18,4 & 78 & 19 & 79,5 \\
\hline & 2019 & 26,1 & 19,4 & 73 & 12 & 78,5 \\
\hline \multirow{3}{*}{ Nautilus } & 2017 & 25,0 & 18,1 & 84 & 10 & 94,2 \\
\hline & 2018 & 25,0 & 18,6 & 90 & 5 & 97,2 \\
\hline & 2019 & 24,5 & 16,0 & 93 & 12 & 91,2 \\
\hline \multirow{3}{*}{ Yakhont } & 2017 & 28,0 & 17,6 & 96 & 5 & 98,6 \\
\hline & 2018 & 29,4 & 19,0 & 89 & 23 & 74,9 \\
\hline & 2019 & 28,6 & 17,7 & 87 & 15 & 86,8 \\
\hline \multirow{3}{*}{ Olimp } & 2017 & 23,6 & 17,3 & 75 & 16 & 98,1 \\
\hline & 2018 & 21,3 & 18,1 & 83 & 8 & 90,2 \\
\hline & 2019 & 23,1 & 18,2 & 83 & 12 & 97,5 \\
\hline \multirow{3}{*}{ Patriot } & 2017 & 28,7 & 17,9 & 83 & 15 & 88,3 \\
\hline & 2018 & 29,4 & 18,0 & 82 & 4 & 90,3 \\
\hline & 2019 & 30,8 & 19,6 & 71 & 9 & 76,2 \\
\hline $\mathrm{LSD}_{05}$ & & 0,3 & 0,09 & 1,2 & 1,1 & 0,7 \\
\hline
\end{tabular}

Mass of 1000 absolutely dry grains for the majority of the studied varieties was maximum in 2018 and exceeded the minimum values of the trait in 2019 for the variety Rapan 2 by $0.6 \mathrm{~g}$, and for Favorit by $3.8 \mathrm{~g}$; in 2017, in the variety Yakhont for $1.4 \mathrm{~g}$. In the variety Nautilus, the values of the trait did not significantly differ in 2017, 2018 and amounted to 25.0 g. Mass of 1000 a.d. grains was the largest for variety Olimp in 2017, and for Patriot in 2019, which is 2.3 and 2.1 g more than in the year with minimal trait values, respectively.

The filminess in the experiment was the greatest in 2018 for the varieties Rapan 2, Nautilus, Yakhont and amounted to $18.4 \%, 18.6 \%$, and $19 \%$ for varieties, respectively. In the varieties Favorit, Olimp and Patriot, the maximum values of the trait were noted in 
2019. In 2017, the filminess was less by $1.4 \%$ for Yakhont, $0.9 \%$ for Olimp, and $1.7 \%$ for Patriot; in 2018 by $1 \%$ in the variety Favorit; in 2019 , by $0.9 \%$ in the variety Rapan 2 , by $2.6 \%$ in the variety Nautilus. The maximum vitreousity in the experiment was noted in 2017 in the varieties Favorit (88\%), Yakhont (96\%) and Patriot (83\%); in 2019 in the varieties Rapan 2 (94\%) and Nautilus (93\%). In Olimp, the values of the trait did not significantly differ in 2018, 2019.Vitreousity decreased in 2017 for Nautilus by $9 \%$ and for Olimp by $8 \%$; in 2018, for the variety Rapan 2 by $2 \%$; in 2019 for Favorit by $15 \%$, Yakhont by $9 \%$, and Patriot by $12 \%$.

The fracturing in the experiment was maximum in the varieties Rapan $2(15 \%)$ and Nautilus (12\%) in 2019; in the varieties Favorit (19\%) and Yakhont (23\%) in 2018; in the varieties Olimp (16\%) and Patriot (15\%) in 2017. Characteristic values decreased in 2017 by $8 \%$ in Favorit, by $18 \%$ in Yakhont; in 2018 , by $4 \%$ in Rapan $2,7 \%$ in Nautilus, $8 \%$ in Olimp and 11\% in Patriot. The head rice content was the smallest in 2018 for the varieties Yakhont (74.9\%) and Olimp (90.2\%); in 2019 in the varieties Rapan 2, Favorit, Nautilus, Patriot. Characteristic values increased in 2017 by $9.8 \%$ in Favorit, by $23.7 \%$ in Yakhont, by $7.9 \%$ in Olimp; in 2018 , by $0.7 \%$ in the variety Rapan $2,6 \%$ in the Nautilus, and $14.1 \%$ in Patriot.

Thus, in the old-delta agrolandscape, in the majority of the studied varieties, the highest values of grain quality traits were noted in 2018, which may indicate the influence of agroclimatic growing conditions in the region.

The relative variability of traits was studied by the coefficient of phenotypic variation, as a measure of the relative variation of the parameter [10]. Expected average values and variability of technological quality traits, the results are presented in Tables 3 and 4.

In the valley agrolandscape, in the majority of studied varieties a mass of 1000 a.d. grains, filminess, vitreousity, fracturing was significantly higher over the years of research than in the old-delta. The opposite pattern was observed in the variety Nautilus for a mass of 1000 a.d. grains, in Yakhont for filminess, in Rapan 2 for vitreousity, and in Patriot for fracturing. The values of the trait "head rice content" were significantly higher for all varieties in the old-delta agrolandscape zone.

Table 3. Mean values and variability of technological grain quality traits of rice varieties grown in the valley agrolandscape

\begin{tabular}{|l|c|c|c|c|c|c|c|c|c|c|}
\hline \multirow{2}{*}{ Variety } & \multicolumn{2}{|c|}{$\begin{array}{c}\text { Mass of } \\
1000 \text { a.d. } \\
\text { grains, g }\end{array}$} & \multicolumn{2}{|c|}{ Filminess \% } & \multicolumn{2}{|c|}{$\begin{array}{c}\text { Vitreousity } \\
\text { \% }\end{array}$} & \multicolumn{2}{c|}{ Fracturing, \% } & \multicolumn{3}{c|}{$\begin{array}{c}\text { Head rice } \\
\text { content, \% }\end{array}$} \\
\cline { 2 - 13 } & $\mathrm{Cv}$ & $\mathrm{Mv}$ & $\mathrm{Cv}$ & $\mathrm{Mv}$ & $\mathrm{Cv}$ & $\mathrm{Mv}$ & $\mathrm{Cv}$ & $\mathrm{Mv}$ & $\mathrm{Cv}$ & $\mathrm{Mv}$ \\
\hline Rapan, st & 5,2 & 23,9 & 4,2 & 19,4 & 1,7 & 92 & 47,6 & 27 & 19,9 & 78,6 \\
\hline Rapan 2 & 6,6 & 23,7 & 3,9 & 20,2 & 4,6 & 92 & 67,6 & 23 & 25,4 & 79,8 \\
\hline Favorit & 3,4 & 27,3 & 6,3 & 18,7 & 3,8 & 84 & 21,2 & 17 & 10,2 & 79,5 \\
\hline Nautilus & 3,2 & 25,2 & 9,9 & 18,1 & 4,0 & 90 & 39,0 & 21 & 11,3 & 82,6 \\
\hline Yakhont & 3,5 & 27,4 & 3,4 & 17,5 & 2,8 & 93 & 32,8 & 15 & 13,6 & 84,9 \\
\hline Olimp & 6,6 & 22,1 & 8,5 & 18,9 & 2,3 & 88 & 35,6 & 23 & 8,2 & 85,6 \\
\hline Patriot & 4,4 & 26,1 & 9,6 & 18,2 & 2,0 & 87 & 14,4 & 22 & 12,6 & 80,6 \\
\hline
\end{tabular}

Note. Cv-variability, Mv. - mean value of the trait

The coefficient of variation for all studied varieties grown in the valley agrolandscape changed according by the trait "mass of 1000 absolutely dry grains " ranging from $3.2 \%$ in the variety Nautilus to $6.6 \%$ in Olimp, "filminess" from $3.4 \%$ in Yakhont to $9.9 \%$ in Nautilus, "vitreousity" from $2.0 \%$ in the variety Patriot to $4.6 \%$ in the variety Rapan 2 , "fracturing" from $14.4 \%$ in Patriot to $67.6 \%$ in Rapan 2, "head rice content" from $8.2 \%$ in 
the variety Olimp to $25.4 \%$ in Rapan 2 . Coefficients of variation in the variety Nautilus for a mass of 1000 a.d. grains, in Yakhont for filminess, in Rapan 2 for vitreousity, in Patriot for fracturing, in Olimp variety for head rice content were the smallest.

Thus, the variation of all the studied traits was weak $(\mathrm{Cv} \leq 10 \%)$, except for the "fracturing", where the variation was medium $(\mathrm{Cv} \geq 10 \%)$ for the varieties Favorit and Patriot and strong $(\mathrm{Cv} \geq 30 \%)$ for Rapan and Rapan 2, Nautilus, Yakhont and Olimp. Variation of the trait "head rice content" was weak for Olimp, average for Favorit, Nautilus, Yakhont, Patriot, Rapan 2. The studied varieties were ranked in series according to the level of variability from low to high: by the trait "mass of 1000 absolutely dry grains "- varieties Nautilus, Favorit, Yakhont, Patriot, Rapan, Rapan 2 and Olimp; by "filminess" - Yakhont, Rapan 2, Rapan, Favorit, Olimp, Patriot, and Nautilus; by "vitreousity" - varieties Rapan, Patriot, Olimp, Yakhont, Favorit, Nautilus, Rapan 2; by "fracturing" - varieties Patriot, Favorit, Yakhont, Olimp, Nautilus, Rapan, Rapan 2; Olimp, Favorit, Nautilus, Patriot, Yakhont, Rapan, Rapan 2 by "head rice content". The varieties Olimp, Patriot and Favorit were recognized as the best varieties in terms of grain quality based on low variability in terms of milling yield quality, fracturing and vitreousity, Yakhont and Favorit - by the totality of traits of grain size and filminess, when grown in the valley agrolandscape zone of Krasnodar region.

The variation coefficient in all studied varieties grown in the old-delta agrolandscape changed by the trait "mass of 1000 absolutely dry grains" ranging from $1.2 \%$ in the variety Nautilus to $6.9 \%$ in Favorit, "filminess" from $2.8 \%$ in Olimp to $7.8 \%$ in Nautilus, "vitreousity" from 1.5\% in Rapan 2 to $8.5 \%$ in Patriot, "fracturing" from $21.8 \%$ in variety Rapan 2 to $62.9 \%$ in Yakhont, "head rice content" from $0.6 \%$ in variety Rapan 2 to $13,7 \%$ in variety Yakhont (Table 4). Thus, the variation of all the studied traits was weak $(\mathrm{Cv} \leq 10 \%)$, except for the "fracturing", where the variation was weak only in varieties Rapan and Rapan 2, the average in the other varieties, and the "head rice content", where the variation was average for Yahont and Rapan. The studied varieties were distributed in a series according to the level of variability from low to high: by "mass of 1000 a.d. grains "varieties Nautilus, Rapan, Rapan 2, Yakhont, Patriot, Olimp, Favorit; "filminess" - varieties Olimp, Favorit, Rapan 2, Yakhont, Patriot, Rapan, Nautilus; "vitreousity" - Rapan 2, Rapan, Yakhont ,Nautilus, Olimp, Patriot, Favorit; "fracturing” - varieties Rapan, Rapan 2, Favorit, Olimp, Nautilus, Patriot, Yakhont; "head rice content" - varieties Rapan 2, Nautilus, Olimp, Favorit, Patriot, Yakhont, Rapan.

Table 4. Mean values and variability of technological grain quality traits of rice varieties grown in the old-delta agrolandscape

\begin{tabular}{|c|c|c|c|c|c|c|c|c|c|c|}
\hline \multirow{2}{*}{ Variety } & \multicolumn{3}{|c|}{$\begin{array}{c}\text { Mass of } 1000 \\
\text { a.d. grains, }\end{array}$} & \multicolumn{2}{|c|}{ Filminess, \% } & \multicolumn{2}{|c|}{ Vitreousity, \% } & \multicolumn{2}{|c|}{ Fracturing, \% } & \multicolumn{2}{|c|}{$\begin{array}{c}\text { Head rice content, } \\
\%\end{array}$} \\
\cline { 2 - 13 } & $\mathrm{Cv}$ & $\mathrm{Cp}$ & $\mathrm{Cv}$ & $\mathrm{Cp}$ & $\mathrm{Cv}$ & $\mathrm{Cp}$ & $\mathrm{Cv}$ & $\mathrm{Cp}$ & $\mathrm{Cv}$ & $\mathrm{Cp}$ \\
\hline Rapan, st. & 1,6 & 25,0 & 5,6 & 20,5 & 4,3 & 88 & 16,9 & 33 & 15,3 & 70,8 \\
\hline Rapan 2 & 1,7 & 25,3 & 3,6 & 18,0 & 1,5 & 93 & 21,8 & 13 & 0,6 & 90,7 \\
\hline Favorit & 6,9 & 28,2 & 2,9 & 18,8 & 9,6 & 80 & 31,1 & 14 & 6,6 & 82,1 \\
\hline Nautilus & 1,2 & 24,8 & 7,8 & 17,6 & 5,2 & 89 & 40,1 & 9 & 3,2 & 94,2 \\
\hline Yakhont & 2,4 & 28,7 & 4,3 & 18,1 & 5,2 & 91 & 62,9 & 14 & 13,7 & 86,8 \\
\hline Olimp & 5,3 & 22,7 & 2,8 & 17,9 & 5,8 & 80 & 33,3 & 12 & 4,6 & 95,3 \\
\hline Patriot & 3,6 & 29,6 & 5,2 & 18,5 & 8,5 & 79 & 59,0 & 9 & 9,0 & 84,9 \\
\hline
\end{tabular}


The values of the trait "head rice content" were significantly higher for all varieties in the old-delta agrolandscape zone.

The varieties Rapan 2, Favorit and Olimp were recognized as the best varieties in grain quality based on low variability in terms of the combination of milling yield quality, fracturing and vitreousity, and Rapan 2 in terms of grain size and filminess when grown in the old-delta agrolandscape zone of Krasnodar region.

\section{Conclusions}

Thus, the potentialities are manifested in different ways in the studied varieties when cultivated in different agrolandscapes. Values of quality traits are significantly higher in all varieties when cultivated in a valley agrolandscape. The best varieties for grain quality on the basis of low variability in total of all quality traits were recognized as Favorit for the valley agrolandscape zone of Krasnodar region (predecessor - fallow field) and Rapan 2 for the old-delta agrolandscape zone (predecessor - winter wheat). According to the absolute values of the traits characterizing the yield and milled rice quality, the best variety was Yakhont in the valley agrolandscape zone, and the variety Nautilus was the best in the olddelta. The placement of rice varieties in the agrolandscape zones of the Krasnodar region is recommended taking into account their reaction to agroclimatic conditions of cultivation.

\section{References}

1. S. Rathi, R.N. Singh Yadav, R.N. Sarma, R. Scien, 17, 4 (2010)

2. T.T. Tu Anh, T.D. Khanh, T.D. Dat, T.D., Agric, 8, 2 (2018) DOI: 10.3390/agriculture8020030.

3. M. Hemalatha, N. Aananthi, R. Suresh, D. Sassikumar, El. J. of Pl. Br. 9, 3 (2018) DOI: 10.5958/0975-928X.2018.00151.5.

4. R.J. González, A. Livore, B. Pons, Braz. Arch. of boil. and tech, 47, 1 (2004) DOI: 10.1590 / S1516-89132004000100010.

5. R. Heydari, N. bagheri, N. Babaeian Jelodar, H. Najafi Zarrini, J. of Cr. Pr. and pr. 9 (2) (2019) DOI: 10.29252/jcpp.9.2.53.

6. N. N. Bassuony, J. Zsembeli, Agr. 65, 3 (2019) DOI: 10.2478/agri-2019-0012.

7. Sv. Tosheva, M. Sabeva, Tr. J. of Sc, 15, 2 (2017) DOI: 10.15547/tjs.2017.02.008.

8. T.R. Sabesan, S.K. Saravanan, El. J. of Pl. Br. 1, 1 (2009)

9. S.Y. Dhurai, D.M. Reddy, P.B. Kumar, El. J. of Pl. Br. 5, 3 (2014)

10. L.V. Agamirov, V.L. Agamirov, V.A. Vestyak, Prog. Pr. i sist.=Soft. Prod. and Syst. 1 (2018) DOI: 10.15827/0236-235X.031.1.166-171

11. N.G. Tumanyan, T.B. Kumejko, G.L. Zelensky, K.K. Olkhovaya, V. I. Gospadinova , T.L. Korotenko, N.V. Ostapenko, Pol. Onl. Sc. J. of Kub. St. Agr. Un. 10, 114 (2015) http://ej.kubagro.ru/2015/10/pdf/114.pdf .

12. E.T. Champagne, K.L. Bett-Garber, C.C. Grimm, A.M. McClung, C. Ch. 84, 4 (2007) DOI: 10.1094/CCHEM-84-4-0320. 